\title{
The Application of SWAT (Soil and Water Assessment Tool) Model to Predict the Hydrology Characteristics Garang Watershed in Central Java Province
}

\author{
Imam Saifudin ${ }^{1, *}$, Suripin ${ }^{2}$, and Suharyanto ${ }^{2}$ \\ ${ }^{1}$ Master of Environment Science, School of Postgraduate Studies Diponegoro University, Semarang 50241, Indonesia \\ ${ }^{2}$ Civil Engineering Department, Engineering Faculty, Diponegoro University, Semarang 50241, Indonesia
}

\begin{abstract}
Intensive and exploitative land use, and a high population growth may reduce the carrying capacity of the environment and affect the hydrological balance. Changes in land use can influence hydrological characteristics, such as surface runoff, coefficient runoff, coefficient of river regime, streamflow maximum and minimum. This study aims to predict the hydrological characteristics of the Garang watershed using SWAT Models. SWAT key data input layer model include a Digital Elevation Model (DEM), soil maps and characteristic of the soil, land use maps and climate data. The results of the model is calibrated and validated using the coefficient of determination $\mathrm{R}^{2}$ and Nash Sucliffe efficiency (NSE). The model results showed in the excellent category.
\end{abstract}

Keywords: Hydrology Characteristics, SWAT, Garang, Watersheds.

\section{INTRODUCTION}

Land use planning is very important to do so does not cause a bad influence on the hydrological characteristics of the watershed. The dynamics hydrological characteristics demonstrate the performance a watershed in securing the availability of water. ${ }^{1}$ Increasing capacity of infiltration and decrease runoff to be a priority in the preparation of land use. The influence of land use on watershed hydrology system is closely related to human activities in land use. The influence of population growth to the increase in land use resulting in changes in forest land use in the upstream Garang watershed. Changes in land use from one type to the other either permanently or temporarily become one focus in watershed management planning. ${ }^{2}$ Land use forest changes in the watershed Garang from 1990 to 2000 amounted to 1957.69 ha to 1769.44 ha led to an increase in surface runoff coefficient $(c)$ from $28 \%$ (1991) to $77 \%$ (2000). ${ }^{3}$

Study land use change on hydrologic characteristics can be done using a hydrological model. ${ }^{4}$ One of the hydrological model which is well used is a model SWAT developed for the USDA (United Stated Department of Agriculture) but it is also recommended to be developed by the association of soil and water conservation world (World Association for Soil and Water Conservation, WASWAC).

*Author to whom correspondence should be addressed.
The SWAT is Ecohydrologi Models ${ }^{5-7}$ has been tested for a wide range of watershed scales and environmental conditions worldwide $^{8-11}$ and has been used extensively to evaluate the impact of land use/land cover (LULC) changes on watershed hydrology, sediment results, nutrient dynamics (among other processes) and water quality. ${ }^{9-13}$ SWAT is a hydrological model that is widely used to evaluate the impacts of climate change, land use, and land management of the hydrological characteristics. ${ }^{14}$ This study aims to predict the hydrological characteristics of the Garang watershed using Model SWAT.

\section{MATERIALS AND METHODS}

\subsection{Description Research Area}

Garang watershed is located in Central Java Province, Indonesia. It has drainage area of $212.77 \mathrm{~km}^{2}$, and situated between latitudes $06^{\circ} 45^{\prime} 18^{\prime \prime}-07^{\circ} 20^{\prime} 45^{\prime \prime} \mathrm{S}$ and between longitudes $105^{\circ} 41^{\prime} 51^{\prime \prime}-109^{\circ} 33^{\prime} 33^{\prime \prime} \mathrm{E}$. The length of the main stream is $40.52 \mathrm{~km} .{ }^{15}$ Garang watershed dominated soil types latosol, which comprised $63.03 \%$ of the entire watershed area Garang.

\subsection{Data Input}

Keys SWAT input data layer include a Digital Elevation Model (DEM), soil maps and soil characteristics, land use maps, and climate data. There are three climatology station (Mijen, 


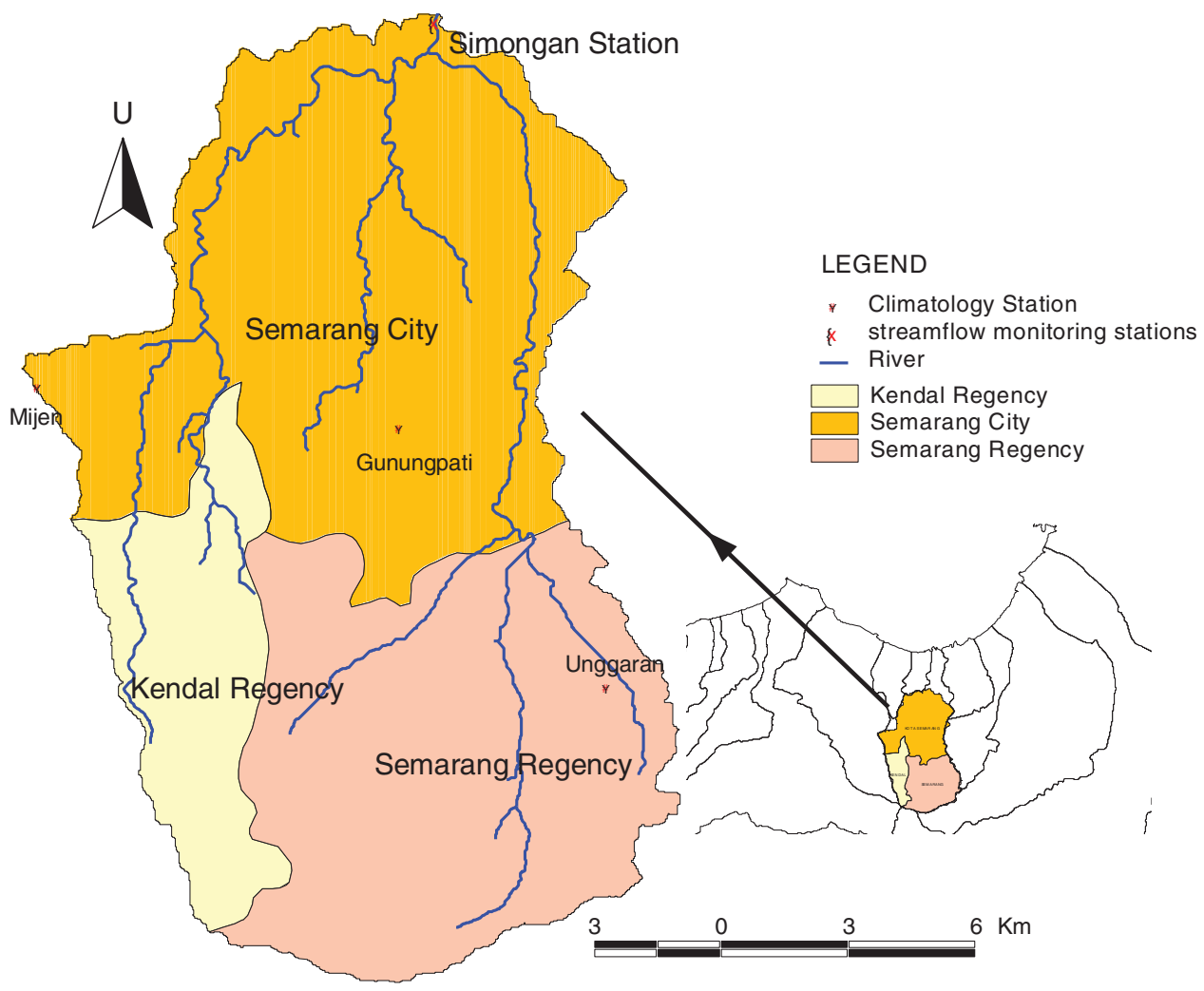

Fig. 1. Map of Garang Watershed showing relative location of meteorological, hydrologic station and stream network.

Gunungpati and Unggaran) that located in Garang Watershed (Fig. 1). In addition there is a streamflow monitoring station (Simongan), which is located at the outlet Garang Watershed.

Ten year of daily meteorological data (2001-2010) were analyzed and processed into mean monthly meteorological statistics to create data that was representative of the study area for SWAT weather generator. Daily minimum and maximum air temperature, wind speed, solar radiation and relative humidity obtained for the three climatology stations are shown in Figure 1 are used for simulation of SWAT.

\subsection{Description of the Model}

The SWAT models regarded as one of the most suitable model to predict the long-term impact of management actions land on water, sediment and results of agricultural chemicals (loss of nutrients) in the watershed large complex with ground varying, land use and conditians management. ${ }^{16,17}$ The SWAT models is based on the physical, conceptual, continuous-time spatial parameter distributed watershed model operates on a daily time step. It is not designed to simulate a detailed, one event routing. ${ }^{18}$

\subsection{Evaluation Model Method}

The performance of the model was evaluated by the coefficient determination $\left(R^{2}\right)$, and Nash-Sutcliffe efficiency (NSE) index. ${ }^{19}$ The $R^{2}$ is the square of the correlation coefficient and can range from 0 to 1 . An $R^{2}$ value of 1 indicated a perfect alignment between predicted and observed values while an $R^{2}$ value of 0 indicates no alignment between predicted and observed values.
The $R^{2}$ can be calculated using the following formula:

$$
R^{2}=\frac{\left[\sum_{t=1}^{n}\left(O_{t}-\hat{O}\right)-\left(P_{t}-\hat{P}\right)^{2}\right]}{\left[\sum_{t=1}^{n}\left(O_{t}-\hat{O}\right)^{2}\right]\left[\sum_{t=1}^{n}\left(P_{t}-\hat{P}\right)^{2}\right]}
$$

Where $P_{t}$ is the magnitude of the predicted value (model), $\hat{P}$ is the value of the average forecast, $O_{t}$ is the value of observation (field) and is the value of the average observation (field). Value for NSE can range between $-\infty$ and 1 . The NSE criteria ${ }^{20}$ include: values between $0.5-0.65$ are acceptable; values between $0.65-0.75$ are good and values that exceed 0.75 are very good. The Nash-Sutcliffe coefficient is calculated as:

$$
\mathrm{NSE}=\frac{\sum_{t=1}^{n}\left(O_{t}-\hat{O}\right)^{2}-\sum\left(P_{t}-O_{t}\right)^{2}}{\sum_{t=1}^{n}\left(O_{t}-\hat{O}\right)^{2}}
$$

\section{RESULTS AND DISCUSSION}

\subsection{Hydrological Response Unit (HRU)}

Watershed delineation process of the networks formed the main river watersheds and 29 subbasins with a total area of 18,951.81 ha. Additionally formed 314 Hydrological Response Unit (HRU).

\subsection{Parameter Calibration}

Table I shows the parameters that affect surface runoff, among others CN2, SOL_AWC, SOL_K, SOL_BD, OV_N, GW_DELAY, GWQMN, CH_N2, CH_K2, ALPHA_BNK, ALPHA_BF, ESCO, and LATTIME. There are 13 parameters that are sensitive to the flow rate that will be carried out for 
Table I. Parameters determined from sensitivity analysis.

\begin{tabular}{|c|c|c|c|c|}
\hline Parameters & Definition & Initial value & $\begin{array}{l}\text { Final } \\
\text { value }\end{array}$ & $\begin{array}{l}\text { Range } \\
\text { value }\end{array}$ \\
\hline CN2 & Curve numbers & $\begin{array}{l}\text { Multiply } \\
\text { original } \\
\text { values }\end{array}$ & 1.085 & $35-98$ \\
\hline SOL_AWC & $\begin{array}{l}\text { Available water } \\
\text { capacity of the soil } \\
\text { layer }\left(\mathrm{mm} \mathrm{H}_{2} \mathrm{O} / \mathrm{mm}\right. \\
\text { soil) }\end{array}$ & $\begin{array}{l}\text { Multiply } \\
\text { original } \\
\text { values }\end{array}$ & 0.05 & $0-1$ \\
\hline SOL_K & $\begin{array}{l}\text { Saturated hydraulic } \\
\text { conductivity }(\mathrm{mm} / \mathrm{hr})\end{array}$ & $\begin{array}{l}\text { Multiply } \\
\text { original } \\
\text { values }\end{array}$ & 0.77 & 0-2000 \\
\hline SOL_BD & $\begin{array}{l}\text { Moist bulk density } \\
\left(\mathrm{g} / \mathrm{cm}^{3}\right)\end{array}$ & $\begin{array}{l}\text { Multiply } \\
\text { original } \\
\text { values }\end{array}$ & 0.71 & $0.9-2.5$ \\
\hline OV_N & $\begin{array}{l}\text { Manning " } n \text { " value for } \\
\text { overland flow }\end{array}$ & $\begin{array}{l}\text { Multiply } \\
\text { original } \\
\text { values }\end{array}$ & 2.85 & $0.01-30$ \\
\hline GW_DELAY & $\begin{array}{l}\text { Groundwater delay } \\
\text { time (days) }\end{array}$ & 31 & 500 & $0-500$ \\
\hline GWQMN & $\begin{array}{l}\text { Threshold depth of } \\
\text { water in the shallow } \\
\text { aquifer required for } \\
\text { return flow to occur } \\
\left(\mathrm{mm} \mathrm{H}_{2} \mathrm{O}\right)\end{array}$ & 1000 & 225 & $0-5000$ \\
\hline CH_N2 & $\begin{array}{l}\text { Coefficient manning } \\
\text { the main channel }\end{array}$ & 0.014 & 0.0175 & $0.01-0.3$ \\
\hline CH_K2 & $\begin{array}{l}\text { Hydraulic conductivity } \\
\text { of river }\end{array}$ & 0 & 180 & $25-500$ \\
\hline ALPHA_BNK & $\begin{array}{l}\text { Baseflow alpha factor } \\
\text { for bank storage } \\
\text { (days) }\end{array}$ & 0 & 0.083 & $0-1$ \\
\hline ALPHA_BF & $\begin{array}{l}\text { Baseflow alpha factor } \\
\text { for bank storage } \\
\text { (days) }\end{array}$ & 0.048 & 0.842 & $0.01-1$ \\
\hline ESCO & $\begin{array}{l}\text { Soil evaporation } \\
\text { compensation factor }\end{array}$ & 0.95 & 1 & $0.01-1$ \\
\hline LAT_TTIME & $\begin{array}{l}\text { Lateral flow travel time } \\
\text { (days) }\end{array}$ & 0 & 175 & $50-180$ \\
\hline
\end{tabular}

calibration, the original parameters used to test the sensitivity analysis are 28 parameters.

\subsection{SWAT Performance}

Observation and simulation data series of river discharge period January 1 to December 31, 2009 (calibration) and January 1 to

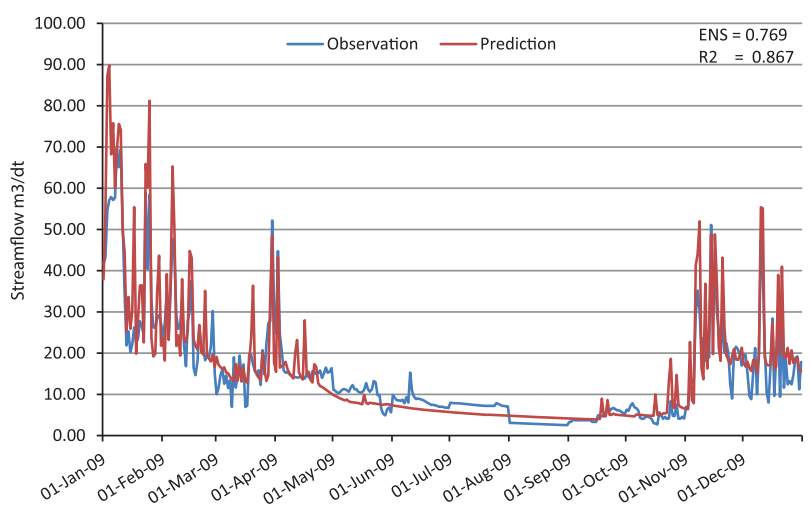

Fig. 2. Relationship streamflow SWAT model results and streamflow observations after being calibration.

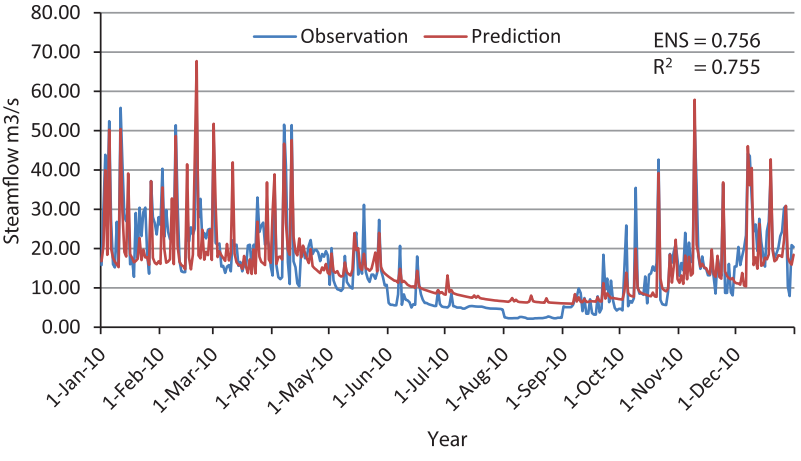

Fig. 3. Relationship streamflow SWAT model results and streamflow observations after being validated.

December 31, 2010 (validation) at the measuring daily basis stations Simongan. The results are as shown in the Figure 2 that some excessive time and some time is reduced, but overall performed well during the simulation. Seen during the calibration period, the value of NSE and $R^{2}$ respectively 0.769 and 0.867 . Relations streamflow SWAT model results and streamflow observations after being validated is shown in Figure 3. The results of the validation is decreasing the value of NSE and $R^{2}$ both have value almost the same, namely 0.755 . These results indicate that the predicted streamflow during periods of extremely accurate calibration, but slightly reduced streamflow measured during the validation period. Calibration and validation results show that the model SWAT including criteria very good.

\subsection{Hydrology Characteristics}

SWAT modeling in Garang Watershed resulted hydrological characteristics. Those were surface runoff was $1645.09 \mathrm{~mm}$, maximum streamflow was $67.71 \mathrm{~m}^{3} / \mathrm{s}$, minimum streamflow was $5.96 \mathrm{~m}^{3} / \mathrm{s}$, interflow was $44.86 \mathrm{~mm}$ and base flow was $915.96 \mathrm{~mm}$. The coefficient of river regim was 11.36, it compared maximum and minimum streamflow and was in good category. Coefficient runoff was 0.53 , that means $53 \%$ of the rainfall went to watershed Garang.

\section{CONCLUSION}

In conclusion, this study shows that SWAT model was applied to Garang watershed, Central Java Province, $(18,951.81$ ha) for the modeling of the hydrological. So the hydrological characteristics of watersheds Garang results for 2010 year was surface runoff was $1,645.09 \mathrm{~mm}$; maximum streamflow $67.71 \mathrm{~m}^{3} / \mathrm{s}$; minimum streamflow was $5.96 \mathrm{~m}^{3} / \mathrm{s}$; coefficient of river regime was 11.36 ; the value of $c$ (coefficient runoff) was 0.53 ; lateral flow was 44.86 and baseflow $915.96 \mathrm{~mm}$.

Acknowledgments: This research supported by the Ministry of Environment and Forestry of Republic Indonesia through the Center for Education and Training of human resources. We wish to thank the Center for Watershed Management Pemali Jratun, Semarang and Masters Program in Environmental Science of Diponegoro University for supporting the success of this study.

\section{References and Notes}

1. Z. Mubarok, Institut Pertanian Bogor (2014).

2. C. Asdak, UGM Press, Yogyakarta (2010). 
3. R. Dewajati, Universitas Diponegoro (2003)

4. S. M. Yusuf, Institut Pertanian Bogor (2010).

5. J. G. Arnold, R. Srinivasan, R. S. Muttiah, and J. R. Williams, Journal of the American Water Resources Association 34, 73 (1998).

6. J. G. Arnold and N. Fohrer, SWAT 2000 Hydrological Processes 19, 563 (2005).

7. J. R. Williams, J. G. Arnold, J. R. Kiniry, P. W. Gassman, and C. H. Green, Hydrological Sciences Journal 53, 948 (2008).

8. P. W. Gassman, M. R. Reyes, C. H. Green, and J. G. Arnold, American Society of Agricultural and Biological Engineers 50, 1211 (2007).

9. K. R. Douglas-Mankin, R. Srinivasan, and J. G. Arnold, Transactions of the ASABE 53, 1423 (2010).

10. P. Tuppad, K. R. Douglas-Mankin, T. Lee, R. Srinivasan, and J. G. Arnold, Transactions of ASABE 54, 1677 (2011).

11. J. G. Arnold, D. N. Moriasi, P. W. Gassman, K. C. Abbaspour, M. J. White, R. Srinivasan, et al., Transactions of the ASABE 55, 1491 (2012).
12. P. W. Gassman, M. Reyes, C. H. Green, and J. G. Arnold, SWAT PeerReviewed Literature: A Review. Proceedings (2007).

13. V. Krysanova and M. White, Hydrological Sciences Journal 53, 939 (2008).

14. J. G. Arnold, J. R. Kiniry, R. Srinivasan, J. R. Williams, E. B. Haney, and S. L. Neitsch, Agricultural Research Service and Texas Agrilife Research (2011)

15. The Center for Watershed Management Pemali Jratun, Central Java (2014).

16. S. Behera and R. K. Panda, Agric. Ecosyst. Environ. 113, 62 (2006).

17. A. Ullrich and M. Volk, Agricultural Water Management 96, 1207 (2009).

18. S. L. Neitsch, J. G. Arnold, J. R. Kiniry, R. Srinivasan, and J. R. Williams, GSWRL Report 02-02, BRC Report 2-06, Temple, Texas, USA (2002).

19. H. Liu, X. L. Chen, and R. Huang, Transactions of the CSAE 27, 306 (2011)

20. D. N. Moriasi, J. G. Arnold, and M. W. Van Liew, Transactions of the ASABE 50,885 (2007).

Received: 12 October 2016. Accepted: 2 November 2016. 